\title{
UJI AKTIVITAS ANTIOKSIDAN EKSTRAK ETANOL DAUN BELUNTAS (Pluchea indica L.) DENGAN METODE DPPH (2, 2-DIFENIL-1-PIKRILHIDRAZIL)
}

\author{
Defitiana Wanita ${ }^{*}$, Rusmini, Finna Ashfia, Fidelia Yustisia Adriane \\ Jurusan Kimia, Universitas Negeri Surabaya, Jl. Ketintang, Surabaya, 60231, Indonesia
}

\author{
*Author Utama, email: defitianawanita@mhs.unesa.ac.id \\ Co-author 1, email: rusmini@.unesa.ac.id \\ Co-author 2, email: finnaashfia@mhs.unesa.ac.id \\ Co-author 3, email: fideliayustisiaadriane@mhs.unesa.ac.id
}

\begin{abstract}
Antioxidant is chemical compound that can give one or more electron to free radical which can obstruct free radical reaction. Beluntas (Pluchea indica L.) is one of plant which potentially as antioxidant. The aim of this research is to determine the antioxidant activity of etanol extract of beluntas leaves. Antioxidant activity test was done by using DPPH (2, 2-diphenyl-1- picrylhydrazil) method. The dry powder of beluntas's leaves was macerated by using ethanol. Ethanol extract obtained was tested antioxidant activity to get IC-50 value by using UV-Vis spectrophotometry at $517 \mathrm{~nm}$. Antioxidant activity test results showed that ethanol extract of beluntas's leaves had IC50 value of 37,25 ppm. So it had antioxidant activity in strong category.
\end{abstract}

Keywords: Antioxidant activity, DPPH, beluntas leaves, ethanol extract

\section{ABSTRAK}

Antioksidan merupakan senyawa kimia yang dapat menyumbangkan satu atau lebih elektron kepada radikal bebas untuk menghambat reaksi radikal bebas. Salah satu tanaman yang berpotensi sebagai antioksidan adalah daun beluntas (Pluchea indica L.). Tujuan penelitian ini adalah untuk menentukan aktivitas antioksidan ekstrak etanol daun beluntas. Pengujian aktivitas antioksidan dilakukan dengan menggunakan metode DPPH (2, 2-difenil-1-pikrilhidrazil). Maserasi serbuk daun beluntas dilakukan menggunakan pelarut etanol. Ekstrak etanol yang diperoleh diuji aktivitas antioksidannya untuk memperoleh nilai IC-50 menggunakan spektrofotometri UV-Vis pada $517 \mathrm{~nm}$. Hasil uji aktivitas antioksidan menunjukkan bahwa ekstrak etanol daun beluntas mempunyai IC 50 sebesar 37,25 ppm, sehingga ekstrak tersebut memiliki aktivitas antioksidan yang tergolong kuat

Kata Kunci: Aktivitas antioksidan, DPPH, daun beluntas, ekstrak etanol

\section{PENDAHULUAN}

Antioksidan merupakan senyawa yang dapat menghambat reaksi oksidasi, dengan mengikat radikal bebas dan molekul yang sangat reaktif sehingga kerusakan sel akan dihambat. Antioksidan terdapat dalam beberapa bentuk, di antaranya vitamin, mineral, dan senyawa metabolit sekunder yang terdapat pada tumbuhan yang memiliki aktivitas antioksidan [1]. Senyawa antioksidan merupakan salah satu senyawa yang dimanfaatkan untuk mencegah proses penuaan dini [2].

Salah satu tumbuhan yang berpotensi memiliki aktivitas antioksidan adalah daun beluntas. Beluntas ( $P$. indica) merupakan tanaman yang termasuk dalam herba famili Asteraceae yang tumbuh secara liar di daerah kering di tanah yang keras dan berbatu atau ditanam sebagai tanaman pagar. Beluntas sering dimanfaatkan sebagai obat tradisional yaitu untuk menghilangkan bau badan dan mulut, mengatasi kurang nafsu makan, 
mengatasi gangguan pencernaan pada anak, menghilangkan nyeri pada rematik, nyeri tulang dan sakit pinggang, menurunkan demam, mengatasi keputihan dan haid yang tidak teratur, hal ini disebabkan adanya kandungan senyawa fitokimia dalam daun beluntas [3].

\section{Klasifikasi Toksonomi}

$\begin{array}{ll}\text { Kingdom } & \text { : Plantae } \\ \text { Divisi } & \text { : Spermatophyta } \\ \text { Sub divisi } & \text { : Angiospermae } \\ \text { Kelas } & \text { : Dycotyledonae } \\ \text { Bangsa } & \text { : Compositales } \\ \text { Suku } & \text { : Compositae } \\ \text { Marga } & \text { : Pluchea } \\ \text { Spesies } & \text { : Pluchea indica (L.) [4]. }\end{array}$

Daun beluntas mengandung sejumlah senyawa fitokimia seperti lignan, terpena, fenilpropanoid, bensoid, alkana [5], sterol, 2(prop-1-unil)-5- (5,6-dihidroksi heksa-1,3-diunil)tiofena, (-)- katekin [6], fenol hidrokuinon, saponin, tanin, alkaloid [7], flavonol (kuersetin, kaemferol, mirisetin) [8]. Kandungan senyawa fitokimia ini menyebabkan daun beluntas mempunyai beberapa aktivitas biologis, salah satunya aktivitas antioksidan. Hasil penelitian sebelumnya menginformasikan bahwa ekstrak etanol daun beluntas telah terbukti mempunyai kemampuan menangkap radikal bebas dari asam 2,2'-azino-bis-(3-etilbensotiasolin-6sulfonat) (ABTS), mereduksi ion besi, dan menghambat oksidasi asam linoleat [9]. Pada penelitian ini akan dilakukan uji aktivitas antioksidan ekstrak daun beluntas menggunakan metode DPPH untuk mengetahui kekuatan aktivitas antioksidannya yang dinyatakan dengan $I C_{50}$. Metode DPPH dipilih karena sederhana, mudah, cepat, dan peka serta hanya memerlukan sedikit sampel. Parameter yang digunakan untuk uji penangkapan radikal $\mathrm{DPPH}$ adalah $I C_{50}$ yaitu konsentrasi ekstrak atau fraksi uji yang dibutuhkan untuk menangkap radikal DPPH sebanyak 50\% [8]. Nilai absorbansi DPPH berkisar antara 515-520 nm [9]. Metode peredaman radikal bebas DPPH didasarkan pada reduksi dari larutan etanol radikal bebas DPPH yang berwarna oleh penghambatan radikal bebas. Ketika larutan DPPH yang berwarna ungu bertemu dengan bahan pendonor elektron maka DPPH akan tereduksi, menyebabkan warna ungu akan memudar dan digantikan warna kuning yang berasal dari gugus pikril [10].

\section{METODE PENELITIAN}

\section{Material}

Bahan yang digunakan dalam penelitian adalah daun beluntas (Pluchea indica L.) yang diperoleh dari wilayah Kecamatan Rungkut, Kota Surabaya, etanol 96\% (p.a dan teknis), radikal DPPH.

\section{Instrumentasi}

Peralatan yang digunakan dalam penelitian ini terdiri dari spektrofotometer UV-Vis (Shimadzu Pharma Spec. UV-1700), rotary vacuum evaporator (Heidolp laborata 4001), timbangan analitik, hot plate, corong buchner, pompa vakum, oven, waterbath, dan peralatan gelas.

\section{Prosedur}

\section{Pembuatan Ekstrak Etanol Daun Beluntas}

Daun beluntas dicuci hingga bersih dan dikeringkan selama 3 hari. Daun beluntas yang sudah kering dihaluskan menjadi serbuk halus. 
Serbuk kering daun beluntas dimaserasi dengan etanol $96 \%$ selama 24 jam dan diulang sebanyak 2 kali. Ekstrak yang diperoleh disaring menggunakan corong buchner. Filtrat yang diperoleh kemudian di evaporasi dengan rotavapor. Kandungan air pada ekstrak etanol dihilangkan menggunakan waterbath.

\section{Uji Aktivitas Antioksidan Ekstrak Etanol Daun Beluntas dengan Metode DPPH}

Sebelum uji dilakukan, disiapkan terlebih dahulu larutan induk ekstrak etanol daun beluntas dengan cara menimbang ekstrak daun beluntas sebanyak $100 \mathrm{mg}$ kemudian dilarutkan dalam $50 \mathrm{~mL}$ etanol $96 \%$. Larutan yang diperoleh selanjutnya dimasukkan ke dalam labu ukur $100 \mathrm{~mL}$ dan diencerkan hingga tanda batas. Kemudian dibuat larutan dengan konsentrasi 2, 4, dan 6 ppm.

Dari masing-masing larutan diambil $2 \mathrm{~mL}$ dimasukkan ke dalam tabung reaksi. Ke dalam masing-masing tabung reaksi, ditambahkan larutan DPPH sebanyak $1 \mathrm{~mL}$. Campuran diinkubasi dalam ruang gelap selama 30 menit. Selanjutnya absorban larutan diukur mengunakan spektrofotometer UV-Vis pada panjang gelombang maksimum $517 \mathrm{~nm}$.

Dari hasil pengukuran absorbansi terhadap tiga jenis larutan dengan konsentrasi berbeda sehingga diperoleh harga persentase inhibisi dan di plot masing-masing pada sumbu $\mathrm{y}$ dan $\mathrm{x}$, dan persamaan garis yang diperoleh digunakan untuk mengitung $I C_{50}$.

\section{HASIL DAN PEMBAHASAN}

\section{Pembuatan Ekstrak Etanol Daun Beluntas}

Ekstraksi daun beluntas dilakukan dengan metode maserasi menggunakan pelarut etanol. Metode maserasi dipilih karena dapat mengekstraksi senyawa aktif dengan baik melalui perendaman tanpa pemanasan sehingga dapat menghindari kerusakan komponen senyawa yang labil dan tidak tahan panas [11].

Hasil dari proses maserasi berupa ekstrak berwarna hijau tua. Ekstrak tersebut kemudian dipekatkan dengan menggunakan rotavapor yang dilengkapi dengan pompa vakum.

Setelah diperoleh ekstrak kental dilakukan pembuatan larutan induk dan diencerkan dengan 3 variasi konsentrasi yaitu 2, 4, dan 6 ppm. Kemudian diuji dengan menambahkan DPPH dengan perbandingan 2:1. Setelah itu dilakukan pengukuran absorban larutan menggunakan spektrofotometer UV-Vis pada panjang gelombang maksimum $517 \mathrm{~nm}$.

Berdasarkan hasil pengukuran absorban, dapat ditentukan harga persentase inhibisi, sebagai dasar penentuan nilai aktivitas antioksidan yang dinyatakan dengan $I_{50}$.

Tabel 1. Hasil uji aktivitas antioksidan ekstrak etanol daun beluntas

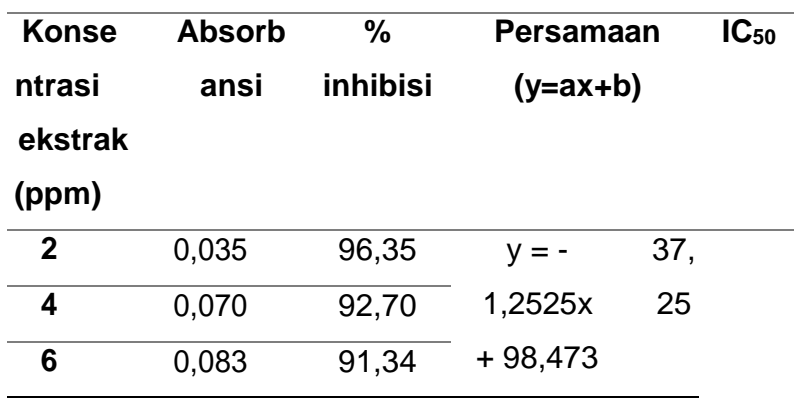

Dari persamaan tersebut diperoleh nilai $I C_{50}$ sebesar 37,25 ppm. Suatu senyawa dikatakan sebagai antioksidan sangat kuat jika nilai $I C_{50}$ kurang dari 50 , kuat (50-100), sedang (100-150), dan lemah (151-200) [12]. Semakin kecil nilai $I C_{50}$ semakin tinggi aktivitas antioksidan. Karena harga $I C_{50}$ kurang dari 50 ppm maka ekstrak etanol daun beluntas memiliki aktivitas antioksidan yang 
(ICAJ) ISSN : 2549-2314;

Volume : 2; Number 2

kuat. Kandungan senyawa fenolik dalam daun beluntas, seperti flavanoid, lignan, dan tanin sangat mendukung tingginya aktivitas antioksidan dari ekstrak etanol daun beluntas.

\section{KESIMPULAN}

Berdasarkan hasil penelitian dan analisis data dapat disimpulkan bahwa ekstrak etanol daun beluntas memiliki aktivitas antioksidan. Aktivitas antioksidan ekstrak tersebut tergolong kuat karena harga IC-50 nya kurang dari 50 ppm yakni 37,25 ppm.

\section{DAFTAR PUSTAKA}

[1] Andarwulan, N. Batari, R. Sandrasari, D.A. dan Wijaya, H. "Identifikasi senyawa flavonoid dan kapasitas antioksidannya pada ekstrak sayuran indigenous Jawa Barat", Half Day Seminar on Natural Antioxidants: Chemistry, Biochemistry and Technology; 2008.

[2] Anese M, Lara M, Maria CN, "Antioxidant Properties of Tomato Juice As Accected By Heating”, J. of The Sci. of Food and Agri., 1999.

[3] Agoes A. 2010. Tanaman Obat Indonesia. Airlangga; Jakarta.

[4] Pujowati P, Pengenalan Ragam Tanaman Lanskap Asteraceae. Bogor: Institut Pertanian Bogor, 2006.

[5] Dean, J. Extraction Techniques In Analytical Science. London: John Wiley And Sons LTD. 2009.

[6] Badarinath A, Rao K, Chetty CS, Ramkanth S, Rajan $\mathrm{T}$, \& Gnanaprakash K. "A Review on In-vitro Antioxidant Methods: Comparisons, Correlations, and Considerations". International Journal of PharmTech Research, 1276-1285. 2010.

[7] Ardiansyah. Nuraida, L. Andarwulan, "Aktivitas antimikroba daun beluntas (Pluchea indica Less) dan stabilitas aktivitasnya pada berbagai konsentrasi garam dan tingkat $\mathrm{Ph}$ ". Jurnal Teknologi dan Industri Pangan., 14(2), 90-97. 2003.

[8] Zou, Y., Lu, Y., dan Wei, D., “Antioxidant Activity of a Flavonoid-Rich Extract of Hypericum perforatum L. In Vitro". J. Agric. Food Chem, 52(1), 5032-5039

[9] Luger, P. Weber, M. Dung, N.X.Ngoc, P.H., Tuong, D.T. dan Rang, D.D., "The crystal structure of hop17(21)-en-3-yl asetat of Plucheapteropoda Hemsl", Crystal Res Technology 35(3), 355-362. 2002.

[10] Biswas, R. Dasgupta, A. Mitra, A. Roy, S.K. Dutta, P.K. Achari, B. Dastidar, S.G. dan Chatterjee, "Isolation, purification and characterization of four pure compounds from the root extract of Pluchea indica Less and the potentiality of the root extract and the pure compounds for antimicrobial activity". European Bulletin of Drug Research, 13 (6370), 2005.

[11] Marxen K, Vanselow KH, Lippemeier S, Hintze R., "Determination of DPPH Radical Oxidation Caused by Methanolic Extracts of Some Microalgal Species by Linear Regression Analysis of Spectrophotometric Measurements". Sensors. 2007.
[12] Prayoga G. Fraksinasi, "Uji Aktivitas Antioksidan dengan Metode DPPH dan Identifikasi Golongan Senyawa Kimia dari Ekstrak Teraktif Daun Sambang Darah (Excoecaria cochinchinensis Lour)". Fakultas Farmasi Program Studi Sarjana Ekstensi Universitas Indonesia. 2013. 